\title{
KAJIAN NILAI TAMBAH AGROINDUSTRI OLAHAN KEDELAI MENJADI KEDELAI BUBUK DI CV. DODO-MIS MARGA ASIH KABUPATEN BANDUNG
}

\author{
STUDY OF THE ADDED VALUE OF PROCESSED SOYBEAN AGROINDUSTRY \\ INTO SOYBEAN POWDER IN CV. DODO-MIS MARGA ASIH BANDUNG \\ REGENCY
}

\author{
Sintya Zahra Aulya*, Dini Rochdiani \\ Universitas Padjadjaran, Jl. Raya Bandung Sumedang KM. 21 \\ *E-mail: sintya.zahra@gmail.com \\ (Diterima 09-12-2019; Disetujui 16-01-2020)
}

\begin{abstract}
ABSTRAK
Kedelai merupakan salah satu komoditas pangan yang penting di Indonesia. Konsumsi kedelai di Indonesia diperkirakan akan terus meningkat setiap tahun. Kedelai tidak dapat dikonsumsi langsung, melainkan harus diolah terlebih dahulu. Meningkatnya konsumsi kedelai menjadikan agroindustri pengolahan kedelai memiliki peluang besar untuk berkembang. Olahan kedelai kuning menjadi sari kedelai memiliki nilai tambah paling tinggi diantara olahan lainnya, namun masih sedikit perusahaan yang bergerak dalam pengolahan kedelai menjadi sari kedelai. CV. Dodo-Mis adalah agroindustri pencetus produk kedelai bubuk khususnya di wilayah Kabupaten Bandung. Desain pada penelitian ini menggunakan desain kualitatif dan teknik penelitiannya studi kasus. Alat analisis yang digunakan yaitu analisis pendapatan dan analisis nilai tambah metode Hayami. Tujuan dari penelitian ini adalah untuk mengetahui pendapatan serta nilai tambah dari proses pengolahan kedelai menjadi kedelai bubuk. Proses pengolahan kedelai menjadi kedelai bubuk di CV. Dodo-Mis terfokus pada 3 variasi rasa yaitu natural, vanila, dan coklat. Proses produksi yang dilakukan masih secara sederhana. Pendapatan CV. Dodo-Mis dari hasil penjualan kedelai bubuk Alamina adalah Rp 3.742.693 sehingga dapat dikatakan usaha ini menguntungkan dengan nilai $\mathrm{R} / \mathrm{C} 1,56$. Nilai tambah terbesar yaitu didapat dari produk kedelai bubuk rasa natural $\mathrm{Rp} 31.415$. Hal ini dikarenakan output kedelai bubuk rasa natural lebih tinggi dan kedelai bubuk natural tidak membutuhkan bahan penunjang dalam proses pembuatannya.
\end{abstract}

Kata kunci: Nilai Tambah, Agroindustri, Kedelai Bubuk

\begin{abstract}
Soybean is one of the important food commodities in Indonesia. Soybean consumption in Indonesia is expected to increase every year. Soybean cannot be consumed directly, but it must be processed first. The increasing consumption of soybean makes soybean processing agroindustry has a great opportunity to develop. Product from processed yellow soybean into soybean powder has the highest added value than the other products, but there are still few companies that process soybean into soybean powder. CV. Dodo-Mis is the first agroindustry that produce soybean powder especially in Bandung Regency area. The design of this study uses qualitative design and research techniques as case studies. The analysis tools used is using income analysis and value added analysis of the Hayami method. The purpose of this study was to determine the income and added value of the processing of soybeans into soybean powder. The process of soybean processing into soybean powder at $C V$. Dodo-Mis is focused on 3 flavor that are natural flavor, vanila flavor, and chocolate flavor. The production process is still simple. The income of CV. Dodo-Mis from the sale of Alamina soybean powder is $R p 3.742 .693$ so it can be said this business is profitable with the $R / C$ score is 1,56 . The biggest added value is obtained from natural flavored soybean powder products. This is because the output of natural soybean powder is higher and natural soybean powder does not require supporting materials in the manufacturing process.
\end{abstract}

Keywords: Value Added, Agroindustry, Soybean Powder 


\section{PENDAHULUAN}

Kedelai (Glycine max) merupakan salah satu komoditas pangan berjenis bijibijian yang penting di Indonesia. Fokus pemerintah terhadap kedelai yaitu telah ditargetkannya swasembada kedelai tercapai pada tahun 2020. Namun ternyata masih banyak hal yang harus dikaji ulang. Menurut peneliti Center for Indonesian Policy Studies (CIPS) Arief Nugraha, kedelai Indonesia belum dapat memenuhi kebutuhan dalam negeri. Kedelai sulit tumbuh optimal di Indonesia yang beriklim tropis karena kedelai merupakan tanaman subtropis (Ekarina, 2019).

Konsumsi kedelai di Indonesia diperkirakan akan terus meningkat setiap tahun seiring dengan bertambahnya jumlah penduduk. Berdasarkan data yang diperoleh dari Pusat Data dan Sistem Informasi Pertanian, konsumsi kedelai di Indonesia diperkirakan akan meningkat tipis dihitung dari tahun 2017 sampai tahun 2021.

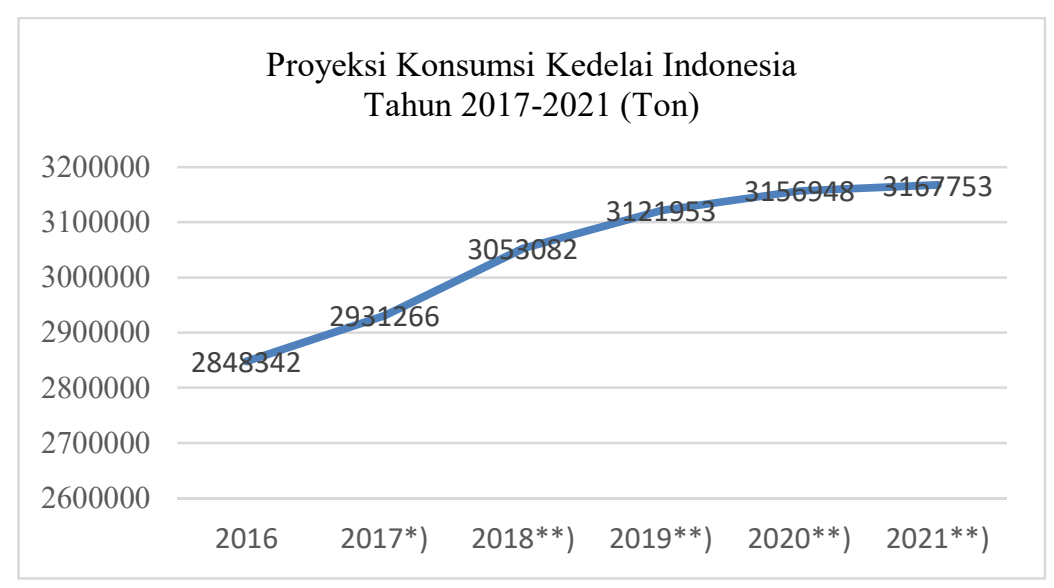

Gambar 1. Proyeksi Konsumsi Kedelai di Indonesia Tahun 2017-2021

Keterangan: *) Angka Ramalan-II

**) Angka Proyeksi Pusdatin

Sumber: Outlook Komoditas Tanaman Pangan dan Hortikultura 2017, Pusat Data dan Sistem Informasi Pertanian

Salah satu alasan banyaknya kebutuhan konsumsi kedelai di Indonesia adalah karena kedelai mengandung banyak manfaat. Seperti yang dikatakan oleh Cahyadi (2007), bahwa kedelai merupakan sumber protein nabati yang efisien, dalam arti bahwa untuk memperoleh jumlah protein yang cukup diperlukan kedelai dalam jumlah yang kecil.

Kedelai tidak bisa dikonsumsi langsung dalam keadaan mentah, melainkan harus melalui proses pengolahan terlebih dahulu sebelum kemudian dikonsumsi. Oleh karena itu, kedelai lebih banyak dipasarkan dalam 
bentuk olahan makanan. Olahan kedelai ini akan memberikan nilai tambah dan meningkatkan pendapatan dari berbagai produk olahannya. Nilai tambah (value added) sendiri merupakan pertambahan nilai suatu komoditas karena mengalami proses pengolahan, pengangkutan ataupun penyimpanan dalam suatu produksi.

Olahan kedelai kuning menjadi sari kedelai memiliki nilai tambah paling tinggi diantara olahan lainnya seperti tahu maupun tempe. Namun, konsumsi kedelai yang sudah diolah berupa sari kedelai belum familiar di masyarakat. Fakta menunjukkan masih sedikit produsen sari kedelai yang terdapat di wilayah Kota Bandung, Kabupaten Bandung dan sekitarnya.

CV. Dodo-Mis merupakan agroindustri yang membuat produk olahan kedelai bubuk dengan merek "Alamina". CV. Dodo-Mis berdiri sejak tahun 2004 dengan bentuk perusahaan $\mathrm{CV}$ (Commanditaire Vennootschap), yaitu jenis badan usaha persekutuan yang belum memiliki badan hukum. Lokasi domisili CV. Dodo-Mis terletak di Jl. Rancamalang no 32, Kecamatan Marga Asih, Kabupaten Bandung, Provinsi Jawa Barat.

Berdasarkan uraian di atas, terlihat bahwa sekalipun proses pengolahan kedelai menjadi sari kedelai memiliki nilai tambah paling tinggi diantara olahan kedelai kuning lainnya, ternyata masih sedikit industri yang bergerak dalam pengolahan sari kedelai di Indonesia. Hal ini menjadi dorongan untuk dilakukan penelitian mengenai pendapatan yang diperoleh dari proses pengolahan kedelai menjadi kedelai bubuk serta besarnya nilai tambah yang dihasilkan dari pengolahan kedelai menjadi kedelai bubuk.

\section{METODE PENELITIAN}

Desain yang digunakan dalam penelitian ini adalah desain kualitatif. Desain kualitatif dipilih karena dalam penelitian ini dibutuhkan pendekatan individu yang mendalam dan terperinci terhadap setiap informan, agar hasil yang didapatkan dapat valid atau benar (Sugiyono, 2009). Metode yang digunakan dalam penelitian ini adalah studi kasus. Bogdan (1990) dalam Idrus (2009) mendefinisikan studi kasus sebagai kajian yang rinci atas suatu latar atau peristiwa tertentu.

\section{Pendekatan Arus Penerimaan dan Arus} Pengeluaran

Arus penerimaan dan arus pengeluaran digunakan untuk mengetahui besarnya pendapatan dari usaha agroindustri olahan kedelai. Arus 
penerimaan dan arus pengeluaran yang digunakan sebagai berikut:

- Arus Penerimaan

- Total Produksi = A $(\mathrm{Kg})$

- Harga Satuan Produksi = Rp B

- Total Penerimaan $(\mathrm{AxB})^{`}=\mathrm{Rp} \mathrm{C}$

- Arus Pengeluaran

Biaya Variabel

- Biaya Bahan Baku $=\mathrm{Rp} D$

- Upah Tenaga Kerja $=$ Rp E

- Bahan Penunjang $=\mathrm{RpF}$

- Bahan Bakar = Rp G

Total Biaya Variabel $(\mathrm{D}=\mathrm{E}=\mathrm{F}=\mathrm{G})=\mathrm{Rp} \mathrm{H}$

Biaya Tetap

- Penyusutan Alat = Rp. I

- Pajak = Rp. J
Total Biaya Tetap $(\mathrm{I}+\mathrm{J})=\mathrm{Rp} . \mathrm{K}$

Total Seluruh Pengeluaran $(\mathrm{H}+\mathrm{K})=$ Rp. L

Analisis pendapatan/keuntungan $(\mathrm{C}-\mathrm{L})=$ Rp. M

$\mathrm{R} / \mathrm{C}(\mathrm{C} / \mathrm{L}) \quad=\mathrm{N}$

\section{Analisis Nilai Tambah Metode Hayami}

Analisis yang digunakan adalah analisis nilai tambah metode Hayami karena metode ini merupakan metode yang umum digunakan untuk menganalisis nilai tambah pada subsistem pengolahan atau produksi. Kerangka analisis perhitungan nilai tambah dengan metode Hayami dapat dilihat pada Tabel 1.

Tabel 1. Analisis Nilai Tambah Metode Hayami

\begin{tabular}{|c|c|c|}
\hline No & Variabel & Nilai \\
\hline \multicolumn{3}{|c|}{ Output, Input dan Harga } \\
\hline 1. & Output $(\mathrm{Kg})$ & (1) \\
\hline 2. & Input $(\mathrm{Kg})$ & (2) \\
\hline 3. & Tenaga Kerja (HOK) & (3) \\
\hline 4. & Faktor Konversi & $(4)=(1) /(2)$ \\
\hline 5. & Koefisien Tenaga Kerja $(\mathrm{HOK} / \mathrm{Kg})$ & $(5)=(3) /(2)$ \\
\hline 6. & Harga produk $(\mathrm{Rp} / \mathrm{Kg})$ & (6) \\
\hline & Upah rata-rata tenaga kerja per $\mathrm{HOK}(\mathrm{Rp} / \mathrm{HOK})$ & (7) \\
\hline \multicolumn{3}{|c|}{ Pendapatan \& Keuntungan } \\
\hline 8. & Harga input bahan baku (Rp/Kg) & $(8)$ \\
\hline 9. & Sumbangan input lain $(\mathrm{Rp} / \mathrm{Kg})$ & (9) \\
\hline 10. & Nilai produk $(\mathrm{Rp} / \mathrm{Kg})$ & $(10)=(4) \times(6)$ \\
\hline & a. Nilai tambah $(\mathrm{Rp} / \mathrm{Kg})$ & $(11 a)=(10)-(8)-(9)$ \\
\hline & b. Tingkat keuntungan $(\%)$ & $(11 b)=(11 a) /(10) \times 100$ \\
\hline & a. Pendapatan tenaga kerja $(\mathrm{Rp} / \mathrm{Kg})$ & $(12 a)=(5) \times(7)$ \\
\hline & b. Imbalan tenaga kerja (\%) & $(12 b)=(12 a) /(11 a) \times 100$ \\
\hline \multirow[t]{2}{*}{13.} & a. Keuntungan $(\mathrm{Rp} / \mathrm{Kg})$ & $(13 a)=(11 a)-(12 a)$ \\
\hline & b. Tingkat keuntungan $(\%)$ & $(13 b)=(13 a) /(10) \times 100$ \\
\hline \multicolumn{3}{|c|}{ Balas Jasa untuk Faktor Produksi } \\
\hline & Marjin $(\mathrm{Rp} / \mathrm{Kg})$ & $(14)=(10)-(8)$ \\
\hline & a. Pendapatan tenaga kerja & $(14 a)=(12 a) /(14) \times 100$ \\
\hline & b. Sumbangan input lain & $(14 b)=(9) /(14) \times 100$ \\
\hline & c. Keuntungan perusahaan & $(14 c)=(13 a) /(14) \times 100$ \\
\hline
\end{tabular}

Sumber: Hayami et.al (1987) 


\section{HASIL DAN PEMBAHASAN}

\section{Biaya Produksi}

Biaya produksi yang dimaksud dalam penelitian ini yaitu seluruh jumlah biaya yang harus dikeluarkan oleh $\mathrm{CV}$. Dodo-Mis selama proses produksi. Pada umumnya biaya dibagi menjadi 2 yaitu biaya tetap (fixed cost) dan biaya variabel (variable cost).

Dalam penelitian ini biaya tetap terdiri atas biaya penyusutan dan pajak bangunan. Dalam proses pengolahan kedelai menjadi sari kedelai bubuk, biaya tetap yang dikeluarkan tidak bergantung pada jumlah hasil produksi. Sementara biaya variabel yang harus dikeluarkan oleh CV. Dodo-Mis berupa biaya bahan baku, biaya bahan penunjang, serta upah tenaga kerja.

Tabel 2. Biaya Tetap, Biaya Variabel dan Biaya

\begin{tabular}{cll}
\multicolumn{3}{c}{ Total } \\
\hline No & \multicolumn{1}{c}{ Uraian } & \multicolumn{1}{c}{ Nilai (Rp) } \\
\hline 1 & Biaya tetap & 32.834 \\
2 & Biaya variable & 2.357 .753 \\
3 & Biaya total & 2.390 .587 \\
\hline
\end{tabular}

\section{Penerimaan}

Sumber penerimaan CV. Dodo-Mis berasal dari penjualan kedelai bubuk Alamina. Dalam penelitian ini yang dimaksud dengan penerimaan yaitu seluruh penerimaan yang diterima oleh $\mathrm{CV}$. Dodo-Mis sebelum dikurangi dengan biaya-biaya yang diperlukan untuk proses produksi kedelai bubuk. Penerimaan $\mathrm{CV}$.
Dodo-Mis setiap satu kali proses produksi dapat dilihat pada Tabel 3.

Tabel 3. Penerimaan CV. Dodo-Mis per Satu Kali Proses Produksi

\begin{tabular}{ccc}
\hline Volume (kg) & $\begin{array}{c}\text { Harga } \\
\text { (Rp/kg) }\end{array}$ & $\begin{array}{c}\text { Penerimaan } \\
(\mathbf{R p})\end{array}$ \\
\hline 80 & 76.666 & 6.133 .280 \\
\hline
\end{tabular}

\section{Pendapatan dan Nilai R/C}

Keuntungan merupakan selisih antara penerimaan yang diterima oleh perusahaan dengan biaya yang harus dikeluarkan dalam satu kali proses produksi. Besarnya pendapatan atau keuntungan yang diperoleh CV. DodoMis dapat dilihat pada Tabel 4.

Tabel 2. Biaya Total, Penerimaan, Pendapatan, dan Nilai R/C Kedelai Alamina dalam Satu Kali Proses Produksi

\begin{tabular}{llc}
\hline No & \multicolumn{1}{c}{ Uraian } & Nilai \\
\hline 1. & Biaya Total & Rp 2.390 .587 \\
2. & Penerimaan & Rp 6.133 .280 \\
3. & Pendapatan & Rp 3.742 .693 \\
4. & Nilai R/C & 1,56 \\
\hline
\end{tabular}

\section{Nilai Tambah}

Nilai tambah merupakan pertambahan nilai yang terjadi pada suatu komoditas karena komoditas tersebut mengalami proses pengolahan lebih lanjut dalam suatu proses produksi. Pengolahan kedelai menjadi kedelai bubuk memberikan nilai tambah serta menghasilkan keuntungan yang dapat dinikmati bagi pelaku usaha nya. Analisis nilai tambah dihitung untuk mengetahui pertambahan nilai kacang kedelai menjadi kedelai bubuk. Untuk menghitung nilai 
tambah dari proses pengolahan kedelai menjadi kedelai bubuk dapat diperoleh menggunakan analisis nilai tambah metode Hayami.

Tabel 3. Analisis Nilai Tambah Metode Hayami untuk Kedelai Bubuk Rasa Natural, Vanila, dan Coklat dalam Satu Kali Proses Produksi

\begin{tabular}{|c|c|c|c|c|}
\hline \multirow{2}{*}{ No } & \multirow{2}{*}{ Variabel } & \multicolumn{3}{|c|}{ Nilai } \\
\hline & & Natural & Vanila & Coklat \\
\hline \multicolumn{5}{|c|}{ Output, Input dan Harga } \\
\hline 1. & Output $(\mathrm{Kg})$ & 32 & 32 & 16 \\
\hline 2. & Input $(\mathrm{Kg})$ & 40 & 40 & 20 \\
\hline 3. & Tenaga Kerja (HOK) & 1 & 1 & 1 \\
\hline 4. & Faktor Konversi & 0,8 & 0,8 & 0,8 \\
\hline 5. & Koefisien Tenaga Kerja (HOK/Kg) & 0,025 & 0,025 & 0,05 \\
\hline 6. & Harga produk $(\mathrm{Rp} / \mathrm{Kg})$ & 76.666 & 76.666 & 76.666 \\
\hline 7. & Upah rata-rata tenaga kerja per $\mathrm{HOK}(\mathrm{Rp} / \mathrm{HOK})$ & 140.000 & 140.000 & 140.000 \\
\hline \multicolumn{5}{|c|}{ Pendapatan \& Keuntungan } \\
\hline 8. & Harga input bahan baku (Rp/Kg) & 7.200 & 7.200 & 7.200 \\
\hline 9. & Sumbangan input lain $(\mathrm{Rp} / \mathrm{Kg})$ & 22.717 & 27.717 & 46.490 \\
\hline 10. & Nilai produk $(\mathrm{Rp} / \mathrm{Kg})$ & 61.332 & 61.332 & 61.332 \\
\hline \multirow[t]{2}{*}{11.} & a. Nilai tambah $(\mathrm{Rp} / \mathrm{Kg})$ & 31.415 & 26.415 & 7.642 \\
\hline & b. Rasio nilai tambah $(\%)$ & $51 \%$ & $43 \%$ & $12 \%$ \\
\hline \multirow[t]{2}{*}{12.} & a. Pendapatan tenaga kerja $(\mathrm{Rp} / \mathrm{Kg})$ & 3.500 & 3.500 & 7.000 \\
\hline & b. Imbalan tenaga kerja (\%) & $11 \%$ & $11 \%$ & $91 \%$ \\
\hline & a. Keuntungan $(\mathrm{Rp} / \mathrm{Kg})$ & 27.915 & 22.915 & 624 \\
\hline & b. Tingkat keuntungan (\%) & $88 \%$ & $86 \%$ & $8 \%$ \\
\hline \multicolumn{5}{|c|}{ Balas Jasa untuk Faktor Produksi } \\
\hline & Marjin $(\mathrm{Rp} / \mathrm{Kg})$ & 54.132 & 54.132 & 54.132 \\
\hline & a. Pendapatan tenaga kerja & $6 \%$ & $6 \%$ & $12 \%$ \\
\hline & b. Sumbangan input lain & $41 \%$ & $51 \%$ & $85 \%$ \\
\hline & c. Keuntungan perusahaan & $51 \%$ & $42 \%$ & $1 \%$ \\
\hline
\end{tabular}

\section{KESIMPULAN DAN SARAN}

\section{Kesimpulan}

Berdasarkan pembahasan data hasil penelitian yang dilakukan di CV. DodoMis, dapat disimpulkan beberapa hal sebagai berikut:

1. Pendapatan yang diterima oleh CV. Dodo-Mis dari hasil penjualan kedelai bubuk yaitu Rp 3.742.693 per proses produksi dengan nilai $\mathrm{R} / \mathrm{C}$ lebih dari 1 yaitu 1,56 yang berarti usaha ini menguntungkan karena setiap pengeluaran satu satuan rupiah akan mendapatkan penerimaan $\mathrm{Rp}$ 1,56 dan keuntungan $\operatorname{Rp} 0,56$.

2. Nilai tambah yang diperoleh CV. Dodo-Mis dari pengolahan kedelai menjadi kedelai bubuk rasa natural yaitu $\mathrm{Rp} 31.415 / \mathrm{kg}$ dengan rasio nilai tambah 51\% (tinggi), rasa vanila $\mathrm{Rp}$ $26.415 / \mathrm{kg}$ dengan rasio nilai tambah $43 \%$ (tinggi), dan coklat yaitu $\mathrm{Rp}$ 7.642 dengan rasio nilai tambah $12 \%$ (rendah). Nilai tambah terbesar berasal dari pengolahan kedelai menjadi kedelai bubuk rasa natural yaitu $\mathrm{Rp}$ $31.415 / \mathrm{kg}$ dan nilai tambah terkecil 
berasal dari pengolahan kedelai menjadi kedelai bubuk rasa coklat yaitu Rp 7.642/kg. Hal ini disebabkan karena dalam proses pengolahan kedelai bubuk natural tidak menggunakan bahan penunjang, melainkan hanya bahan baku kacang kedelai saja sehingga biaya yang dikeluarkan lebih sedikit. Selain itu, input dan output yang dihasilkan lebih banyak karena permintaannya pun lebih banyak daripada kedelai bubuk rasa coklat.

\section{Saran}

Berdasarkan hasil penelitian yang telah disimpulkan di atas, terdapat beberapa temuan yang dapat dijadikan saran untuk pengembangan lebih lanjut. CV Dodo-Mis disarankan untuk tetap terus berusaha mengembangkan usaha pengolahan kedelai menjadi kedelai bubuk. Hal ini dapat dilakukan dengan cara:

1. Melakukan kaderisasi generasi penerus usaha, mengingat pemilik saat ini mengalami kejenuhan karena telah cukup lama bekerja.

2. Secara bertahap melakukan penggantian tenaga kerja produksi, mengingat tenaga kerja yang ada saat ini hampir seluruhnya sudah berumur lebih dari 50 tahun. Penggantian dapat dilakukan dengan merekrut tenaga kerja baru melalui pembukaan lowongan pekerjaan.

3. Melakukan perubahan harga untuk tiap varian produk yang dihasilkan, mengingat adanya nilai tambah yang berbeda. Hal ini bertujuan agar tingkat marjin pendapatan yang diperoleh dapat lebih baik.

4. Bagi pihak pemerintah, disarankan untuk lebih fokus dalam membantu pengembangan usaha pengolahan kedelai, baik dari aspek ketersediaan bahan baku, aspek teknis produksi, aspek pemasaran, aspek kelembagaan usaha, maupun aspek kemudahan mendapatkan bantuan permodalan. Hal ini bertujuan agar minat usaha semakin meningkat.

\section{DAFTAR PUSTAKA}

Cahyadi, Wisnu. 2007. Kedelai Khasiat dan Teknologi. Jakarta: PT. Bumi Aksara.

Ekarina. 2019. Produktivitas Rendah, Target Swasembada Kedelai Diminta DIkaji Ulang. https://katadata.co.id/berita/2019/01 /09/produktivitas-rendah-targetswasembada-kedelai-dimintadikaji-ulang. Diakses 29 September 2019.

Hayami, Yujiro. 1987. Agricultural Marketing and Processing in Unpland Java, A Perspective From A Sunda Village. CGPRT. Bogor. 
Idrus, Muhammad. 2009. Metode Penelitian Ilmu Sosial, Pendekatan Kualitatif dan Kuantitatif. Jakarta : Erlangga.

Pusat Data dan Sistem Informasi Pertanian Sekretariat Jenderal, Kementerian Pertanian. 2017. Outlook Komoditas Tanaman
Pangan dan Hortikultura. http://epublikasi.pertanian.go.id/ars ip-outlook/537-outlook-tphorti2017. Diakses 18 Maret 2019.

Sugiyono. 2009. Metode Penelitian Kuantitatif, Kualitatif, dan $R \& D$. Bandung: Alfabeta. 